\title{
The Multi-Level Data Exchange with Representational State Transfer on Service-Oriented Architecture
}

\author{
Worrapong Nuam-In, Prachyanun Nilsook, and Panita Wannapiroon
}

\begin{abstract}
In order for government organizations to be geared towards digital government they need to have the basic systems in terms of hardware, software, systems and data in order to support integration. Therefore, the exchange of government data is considered to be the major factor in developing digital government. This article aims to design the service-oriented architecture (SOA) for data exchange within the Ministry of Education in Thailand which has a varied internal structure, by using REST as the "Architectural style" and JSON as the standard for exchanging data according to the information standard that is prescribed by the Ministry of Education.
\end{abstract}

Index Terms-Data exchange, representational state transfer, REST, service-oriented architecture, SOA.

\section{INTRODUCTION}

Government agencies need to progress to digital government by ensuring integration between agencies, introducing a smart working system, being people-centered and propelling the entire change based on 4 actions: (1) Government Integration - the introduction of data integration and co-operation between agencies (2) Smart Operations - introducing the appropriate technology and digital gadgets to support the operation (3) Citizen-centric Services - enhancing the government service to serve the population needs (4) Driven Transformation - being a digital government throughout the entire organization in terms of personnel, operations procedure, technology and regulations [1]. The integration of population database and service government reform plan (B.E. 2560-2564) prescribes the procedures for the integration of the population database and government services. This involves the development of the Population Information Linkage Center which links the data system between the Population Information Linkage Center and the Civil Registration Database, and improves the population service system [2] The Ministry of Education is a

Manuscript received January 20, 2019; revised October 30, 2019.

Worrapong Nuam-In is with Division of Information and Communication Technology for Education, Faculty of Technical Education, King Mongkut's University of Technology North Bangkok (KMUTNB), Bangkok, Thailand (e-mail: nuamin@gmail.com).

Prachyanun Nilsook is with Vocational Education Technology Research Center, Science and Technology Research Institute, King Mongkut's University of Technology North Bangkok (KMUTNB), Thailand (e-mail: prachyanun@kmutnb.ac.th).

Panita Wannapiroon is with Innovation and Technology Management Research Center, Science and Technology Research Institute, King Mongkut's University of Technology North Bangkok (KMUTNB), Thailand (e-mail: panitaw@kmutnb.ac.th). complicated and large scale organization which is currently unable to transfer and exchange data [3] completely. Therefore, the use of Information and Communication Technology in the educational context is necessary. Service-oriented Architecture (SOA) is the concept related to the design of an information technology system within government agencies aimed at putting into place a service system which is reusable, and which support the development system with independence and different to integrate between them [4], [5].

\section{BACKGROUND}

\section{A. Multi-level Data Flow of MOE}

Transferring the education data of the Ministry of Education (MOE) begin with the schools in each regional cluster. Individuals schools will collect and transfer data to their regional cluster offices - the Educational Service Area Office. These regional offices will then collect, check and transfer data to the central office. Some schools are currently able to transfer the data directly to the central office. The central office is composed of the Office of the Basic Education Commission, the Office of the Vocational Education Commission, the Office of the Higher Education Commission, the Office of the Private Education Commission, and the Office of Non-Formal and Informal Education [6]. Each central office will collect, check, store and transfer data to the Information and Communication Technology Center of the Ministry of Education. In the event of complicated or error data, the data will be sent back to the data owner which is the central office, the regional office and the school in sequential order. The data owner will update and improve the data then transfer it back again [7]. This is shown in Fig. 1.

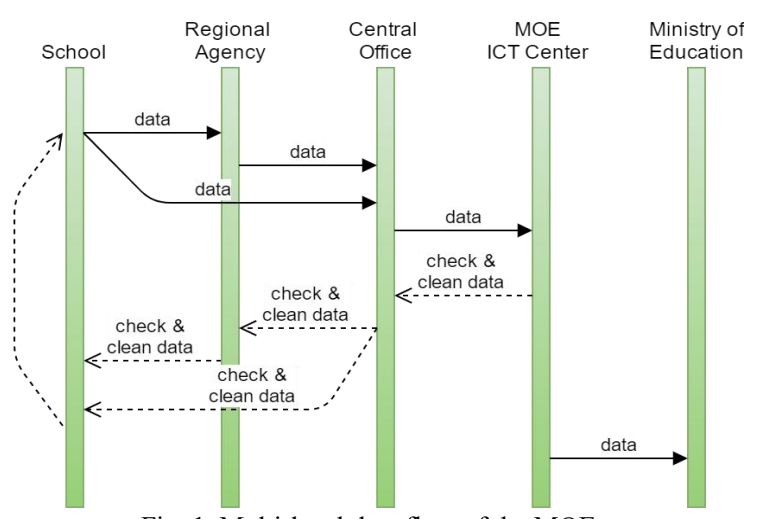

Fig. 1. Multi-level data flow of the MOE.

\section{B. MOE Data Standard}

The MOE prescribes and publicizes the standard of 
education data for the internal and external sectors in such a

Student Data: 46 fields and (2) Graduate Student Data: 23 way that they are able to exchange and integrate the data. The data standard in this study consists of 2 components: (1)

fields [8] as indicated in Tables I and II.

TABLE I: STUDENT

\begin{tabular}{|c|c|c|c|c|}
\hline No & Fieldname & Type & Length & Description \\
\hline 1 & AcademicYear & Varchar & 4 & Academic year of data collection \\
\hline 2 & Semester & Varchar & 1 & Semester of data collection \\
\hline 3 & SchoolID & Varchar & 10 & School code \\
\hline 4 & JurisdictiontID & Varchar & 2 & Code of original affiliation \\
\hline 5 & JurisdictionPK & Varchar & 50 & Student Code \\
\hline 6 & StudentID & Varchar & 15 & Student Identification Number \\
\hline 7 & PersonID & Varchar & 13 & Personal Identification Number \\
\hline 8 & PassportNumber & Varchar & 20 & Passport Number (cited authority by Ministry of Foreign Affairs) \\
\hline 9 & PrefixCode & Varchar & 3 & Title (Cited Department of Provincial Administration) \\
\hline 10 & FirstName & Varchar & 100 & Name \\
\hline 11 & MiddleName & Varchar & 100 & Middle name \\
\hline 12 & LastName & Varchar & 100 & Last name \\
\hline 13 & GenderCode & Integer & 1 & Gender code (cited core standard code of the Ministry of Education) \\
\hline 14 & Birthdate & Varchar & 8 & Date of birth (YYYYMMDD) \\
\hline 15 & NationalityCode & Varchar & 3 & Nationality code (cited core standard code of the Ministry of Education) \\
\hline 16 & DisabilityCode & Varchar & 2 & Disability code of physical and mental health (cited 9 types of disabilities of OBEC) \\
\hline 17 & Disadvantaged EducationCode & Integer & 2 & $\begin{array}{l}\text { Educational Disadvantaged code (cited } 11 \text { typed of Educational Disadvantaged of } \\
\text { OBEC) }\end{array}$ \\
\hline 18 & RegisterHouseID & Integer & 11 & House code number (cited copy of house registration) \\
\hline 19 & RegisterHouseNumber & Varchar & 100 & Address (cited copy of house registration) \\
\hline 20 & RegisterVillageNumber & Varchar & 100 & Number of village (cited copy of house registration) \\
\hline 21 & RegisterStreet & Varchar & 100 & Name of road (cited copy of house registration) \\
\hline 22 & RegisterSoi & Varchar & 100 & Name of lane (cited copy of house registration) \\
\hline 23 & RegisterTrok & Varchar & 100 & Name of alley (cited copy of house registration) \\
\hline 24 & RegisterSubDistrictCode & Integer & 6 & Regional code (province, district, subdistrict) \\
\hline 25 & FatherPrefixCode & Varchar & 3 & Title (Cited Department of Provincial Administration) \\
\hline 26 & FatherFirstName & Varchar & 100 & Father's name \\
\hline 27 & FatherMiddleName & Varchar & 100 & Father's middle name \\
\hline 28 & FatherLastName & Varchar & 100 & Father's last name \\
\hline 29 & FatherStatusCode & Integer & 1 & Code of father's status \\
\hline 30 & MotherPrefixCode & Varchar & 3 & Title (Cited Department of Provincial Administration) \\
\hline 31 & MotherFirstName & Varchar & 100 & Mother's name \\
\hline 32 & MotherMiddleName & Varchar & 100 & Mother's middle name \\
\hline 33 & MotherLastName & Varchar & 100 & Mother's last name \\
\hline 34 & MotherStatusCode & Integer & 1 & Code of mother's status \\
\hline 35 & $\begin{array}{l}\text { EducationLevel } \\
\text { AdmissionYear }\end{array}$ & Varchar & 4 & Year of admission/ current education level (B.E.) \\
\hline 36 & SchoolAdmissionYear & Varchar & 4 & Year of school admission \\
\hline 37 & EducationLevelCode & Varchar & 2 & Current code of education level \\
\hline 38 & GradeLevelCode & Integer & 3 & Current grade level \\
\hline 39 & CurriculumCode & Integer & 2 & Curriculum code \\
\hline 40 & MajorCode & Integer & 2 & Major code \\
\hline 41 & ProgramCode & Integer & 2 & Study program code \\
\hline 42 & CourseCode & Integer & 2 & Course code \\
\hline 43 & GPA & Decimal & 4 & GPA scores \\
\hline 44 & GPAX & Decimal & 4 & Grade Point Average \\
\hline 45 & LearningCenterProvince & Integer & 2 & Provincial code \\
\hline 46 & PartnerSchoolID & Varchar & 10 & School code \\
\hline
\end{tabular}

TABLE II: GRADUATES

\begin{tabular}{|c|c|c|c|c|}
\hline No & Fieldname & Type & Length & Description \\
\hline 1 & PersonID & Varchar & 13 & $\begin{array}{l}\text { Personal Identification } \\
\text { number }\end{array}$ \\
\hline 2 & Prefix & Varchar & 40 & Title \\
\hline 3 & FirstName & Varchar & 40 & Name \\
\hline 4 & LastName & Varchar & 50 & Last name \\
\hline 5 & Birthdate & $\begin{array}{l}\text { ววดดปป } \\
\text { ปป }\end{array}$ & 8 & Date of Birth \\
\hline 6 & $\begin{array}{l}\text { RegisterHouse } \\
\text { Number }\end{array}$ & Varchar & 10 & Address \\
\hline 7 & $\begin{array}{l}\text { RegisterVillage } \\
\text { Number }\end{array}$ & Varchar & 2 & Number of village \\
\hline 8 & RegisterStreet & Varchar & 80 & Name of Road \\
\hline 9 & RegisterSoi & Varchar & 80 & Name of Lane \\
\hline 10 & RegisterTrok & Varchar & 80 & Name of Alley \\
\hline 11 & SubDistrict & Varchar & 80 & Name of subdistrict \\
\hline 12 & District & Varchar & 80 & Name of district \\
\hline 13 & Province & Varchar & 60 & Name of province \\
\hline 14 & NationalityName & Varchar & 40 & Name of nationality \\
\hline 15 & SchoolID & Varchar & 10 & School code \\
\hline
\end{tabular}

\begin{tabular}{|c|l|c|c|l|}
\hline No & \multicolumn{1}{|c|}{ Fieldname } & Type & Length & \multicolumn{1}{|c|}{ Description } \\
\hline 16 & SchoolName & Varchar & 120 & Name of school \\
\hline 17 & AcademicLevel & Varchar & 17 & Academic levels \\
\hline 18 & CurriculumShort & Varchar & 10 & $\begin{array}{l}\text { Abbreviation for } \\
\text { degrees }\end{array}$ \\
\hline 19 & Curriculum & Varchar & 100 & Degrees \\
\hline 20 & Program & Varchar & 100 & Study program \\
\hline 21 & GPA & Decimal & 4 & GPA scores \\
\hline 22 & $\begin{array}{l}\text { FinalApproval } \\
\text { Date }\end{array}$ & Varchar & 8 & Date of import data \\
\hline 23 & dateUpdate & Varchar & 8 & Date of updated data \\
\hline
\end{tabular}

\section{A. Data Exchange \& Communication Protocol}

This study uses the Representational State Transfer (REST) style because it is simple and easy to use. It can be used to access the code message while transferring the data of the RESTful web services. JavaScript Object Notation (JSON) can transfer the data in the form of the minimization 
data exchange. Therefore, JSON is selected for use in this study [9].

REST is the standard Architecture Style, using JSON to receive and transfer data which is easy to access through URL. The result shows that the data set can process the JSON message code, receive and transfer data specifically through HTTP, and is easy to access using JavaScript. It is more effective than SOAP which use less CPU processor power and a simpler code [10].

Examples of JSON used to transfer Student data and Graduate data:

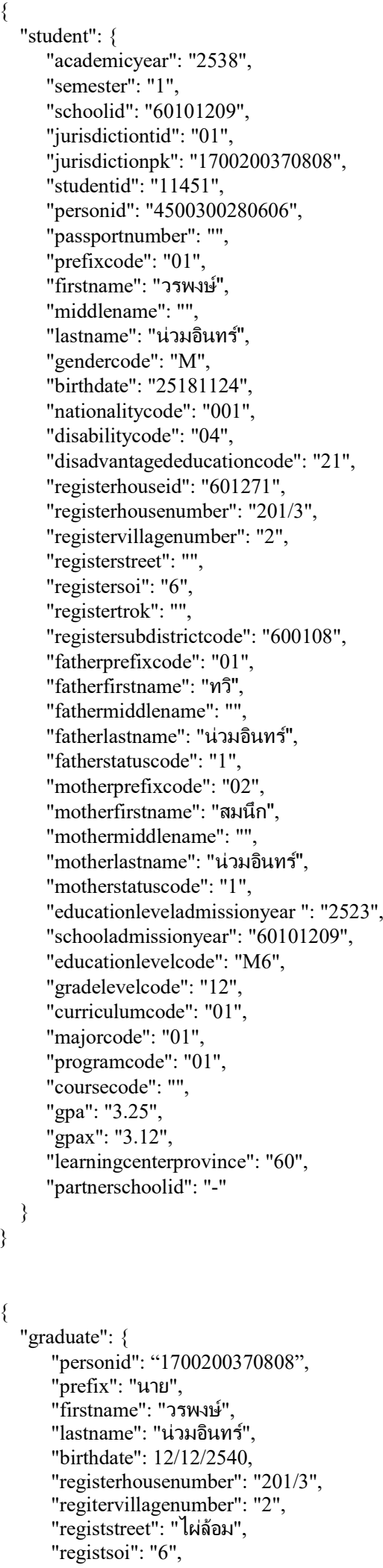

"registtrok": "-",

"subdistrict": "ป่ากน้ำโพ",

"district": "เมืองนครสวรรค์",

"province": "นครสวรรค์",

"nationalityname": "ไทย",

"schoolid": "6001010140",

"schoolname": "ลาซาลโชติรวีนครสวรรค์",

"academiclevel": "มัธยมศึกษาตอนปลาย",

"curriculumshort": "ม.ปลาย",

"curriculum": "การศึกษาขั้นพื่นฐาน",

"program": "-",

"gpa": 3.02 ,

"finalapprovaldate": "01/03/2561",

"dateupdate": "15/05/2561"

\}

\}

\section{SERVICE-ORIENTED ARCHITECTURE: SOA}

Service-Oriented Architecture (SOA) is an Architectural Style which is based on a design pattern which is based on the different components of software that have a function for other applied programs through the protocol standard. SOA is a set of services that focus on communication. Communication involves simple data transferring until certain feature the work of two or more services.

SOA for web service has the following:

A standard for communication

The same presentation pattern and data exchange

The details of language which are describable

A registration and searchable pattern on the web service system

Therefore, SOA is an approach that has been used to design the architecture for the service. RESTful is a service which processes small functions such as data setting, data approved from clients, or other basic services [10], [11].

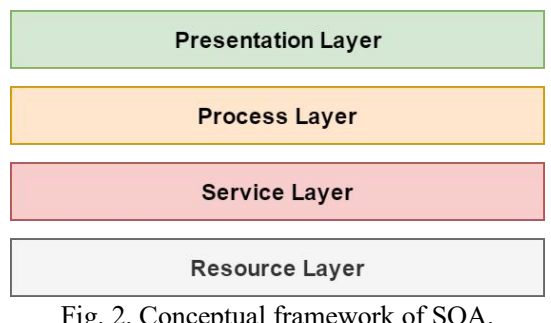

\section{MOE DATA EXCHANGE ON REST-SOA}

As can be seen in Fig. 3 (left) in terms of the original system of data exchange, the schools transfer data to the central agencies in 2 forms: (1) transfer in the form of Text Files (CSV File or Excel File) by transferring from the File Transfer Protocol (FTP). The Information and Communication Technology Center of the Ministry of Education will examine the files to ensure that they are completely accurate and not over-complicated. Then, it stores the data the database system and (2) transfer in the form of Web Service [12], [13] which uses XML Protocol for transferring and storing data in the database system.

The Service-Oriented Architecture (SOA) for data exchange within the Ministry of Education that has various internal structures is done by using REST as the "Architectural style" and JSON as the standard for exchanging data according to the information standard that has been prescribed by the Ministry of Education. From Fig. 
3 (right) it can be seen that the schools can transfer data using the original standard, and it will be changed for access purposes using JSON. The schools and the central agencies can transfer the data directly to the Information and
Communication Technology Center of the Ministry of Education in form of RESTful web services that uses the JSON Protocol through the REST Service Gateway and which then stores the data in the database system [14]-[19].
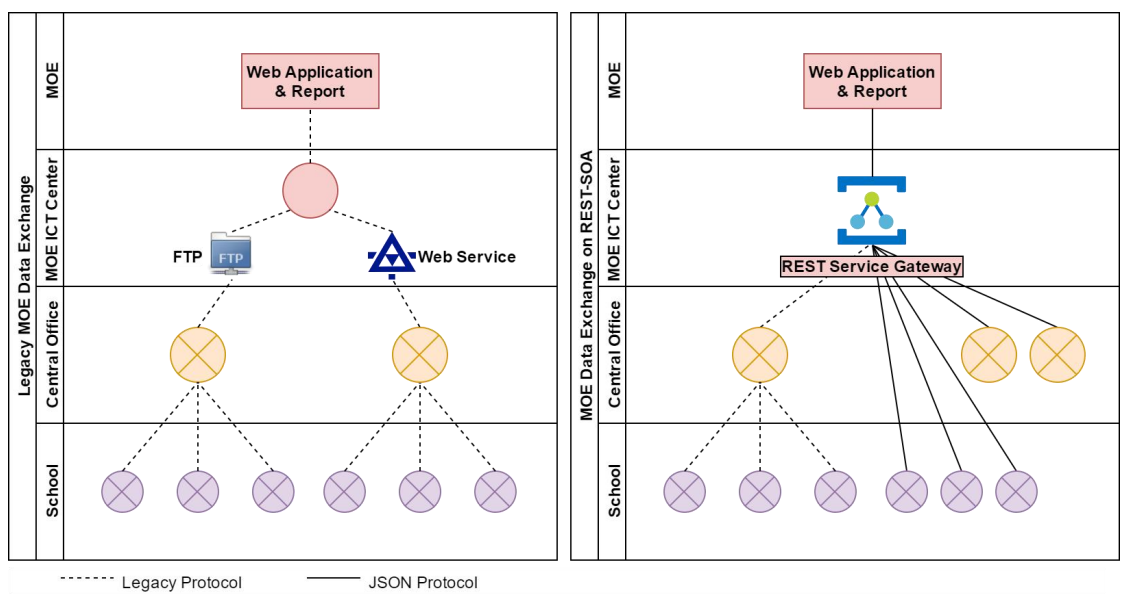

Fig. 3. Legacy MOE data exchange (left) and MOE data exchange on REST-SOA (right).

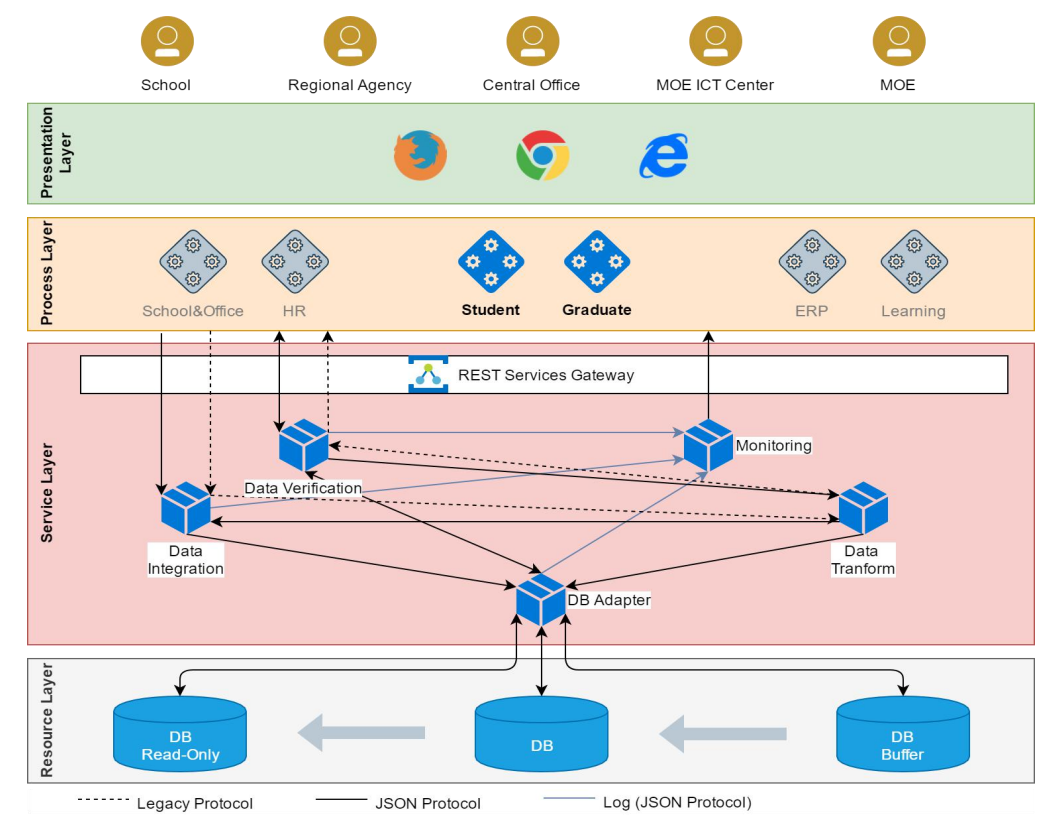

Fig. 4. MOE data exchange on REST-SOA architectural framework.

The design of the MOE Data Exchange on REST-SOA Architectural Framework can be seen in Fig. 4. The architecture is divided into 4 layers, consisting of:

1) Resource Layer. This is the section of resources that is used in storing the data and files. The database can be separated into 3 databases in the form of (1.1) DB Buffer. This is the database used for storing and hanging data to check for accuracy and complications (1.2) DB. This is the main database containing accurate data and (1.3) DB Read-only. This is the main database containing accurate data what is ready for other departments to use.

2) Service Layer is the part that stores all the service. By using the REST Services Gateway is the main service serves as a Service Bus connect Process Layer includes 5 services. As follows:

2.1) DB Adapter Service. This is the center for linkage and converting data for storage in 3 databases.

2.2) Data Integration Service. This is a part for receiving data from schools and central agencies. The data is transferred in 2 types; legacy protocol and JSON protocol. In the case of the legacy protocol, this will retransfer data to be converted into JSON at the Data Transform Service, and transferred back to the DB Adapter for converting and storing in the database system.

2.3) Data Verification Service. This is a part that examines data for complications and accuracy. If the data lacks accuracy and is complicated, the Data Verification Service will download the data and transfer it back to the owners. They can then improve and return the data. In the event that the data owners use legacy protocol, the system will transfer the data for conversion by the Data Transform Service. After converting, the data is transferred back to the owners.

2.4) Data Transform Service. This is a part that converts data between legacy protocol and JSON protocol.

2.5) Monitoring Service is a part that is used to store the status of operation information include: sending and receiving data, data transformation and commit data into database system.

3) The Process Layer is a part of the business process that 
is developed from the service components. Get the value that the user enters into the Service Layer. Special conditions can meet the requirements of the work. It may be the requirement for each task to be done, such as checking the data received from user interface, according to the specified conditions. Record a transaction that must be recorded in a student table and a graduate table.

4) The Presentation Layer is the top part of receiving the presentation or rendered as a contact with the user interface, which is running Business Logic from the developed Process Layer. Users can use the improved program. Therefore, it must be designed for use and user-friendly may be a web application or mobile application.

\section{CONCLUSION}

The study of the Multi-Level Data Exchange with Representational State Transfer on Service-Oriented Architecture (SOA) uses REST as the Architectural style and JSON as the standard of exchange data. This study uses 2 data standards: student data standard and graduate student data standard. The framework of the architecture which is designed consists of 4 layers; the Resource Layer, the Service Layer, the Process Layer, and the Presentation Layer. The Rest Service Gateway is the center for exchanging data. There are 5 important internal services: the DB Adapter Service, the Data Integration Service, the Data Verification Service, the Data Transform Service, and the Monitoring Service. A further study will deal with the architecture designed to develop and implement the system which is used by schools and departments under the MOE. The MOE will have to transfer the educational data into a unified and standardized form, both in terms of data standards and standard exchange. As a result, the processing of educational information is a convenient and faster to assist decision-making for executives. It can also be integrated with other government agencies. This is the most important basis for the response to (1) The National Education Plan (for B.E. 2560-2579) [20], (2) The Digital Development Plan to Economy and Society [21], and (3) A National Strategy (for B.E. 2561-2580) [22], and will lead to sustainable development with regard to education in Thailand.

\section{CONFLICT OF INTEREST}

"The authors declare no conflict of interest".

\section{AUTHOR CONTRIBUTIONS}

Worrapong Nuam-In concuted the research, analyzed the data and wrote the paper. All authors had approved the final version.

\section{ACKNOWLEDGMENTS}

This research was partially supported by the Graduate Thesis Research Grant (GTRG) from the Graduate College, King Mongkut's University of Technology North Bangkok under award number 133/fiscal year 2561. The researchers would like to express their sincere gratitude to the Vacation Education Technology Research Center of the Science and Technology Research Institute, King Mongkut's University of Technology North Bangkok, and the Office of the Basic
Education Commission for supporting this research.

\section{REFERENCES}

[1] Digital Government Development Agency (Public Organization) (DGA). (2017). The digital government development plan of Thailand. [Online]. Available: https://www.ega.or.th/upload/download/file_3763d050adbcd30d17a7 7a5288883bcf.pdf

[2] The public service government and integrated database. Department of Provincial Administration. (2017). The action plan driven database integration and public service government (B.E. 2560 - 2564). [Online]. Available: http://www.dnp.go.th/banpong/plan/plan/files/69_27042560Plan5year s.pdf

[3] A. Yaowong and P. Piriyasurawong, "Synthesis components and electronic information data interchange model for knowledge management in educational administration," J. Adv. Manag. Sci., vol. 2, no. $1,2014$.

[4] R. Baraka and S. Madoukh, "A SOA-based e-government data integration," International Arab Journal of e-Technology, pp. 138-145, vol. 3, 2014.

[5] Y.-J. Qi and Z.-P. Dan, "Data exchange and integration mechanism of E-government based on SOA-study about education e-government," Computer Technology and Development, 2015.

[6] Ministry of Education. (2013). Information about the agency. [Online]. Available: http://www.moe.go.th/moe/th/office/strucMOE56.pdf

[7] Ministry of Education. (2015). The working process in the monitoring of data redundancy. [Online]. Available: http://www.mis.moe.go.th/mis2018/images/กระบวนการ.pdf

[8] Ministry of Education. (2019). MOE data standard. [Online]. Available: http://www.standardcode.moe.go.th/

[9] P. Jiang, M. Elag, P. Kumar, S. D. Peckham, L. Marini, and L. Rui, “A service-oriented architecture for coupling web service models using the Basic Model Interface (BMI)," Environ. Model. Softw., vol. 92, pp. 107-118, Jun. 2017.

[10] E. S. Motlagh, "A survey of service oriented architecture systems testing," Int. J. Softw. Eng. Appl., vol. 3, no. 6, pp. 19-27, Nov. 2012.

[11] M. Wagner, D. Zöbel, and A. Meroth, "An adaptive software and systems architecture for driver assistance systems based on service orientation," Int. J. Mach. Learn. Comput., vol. 1, no. 4, pp. 359-365, 2013.

[12] C. C. Lin, Y. McLee, and J. H. Kuo, "Web services: Themes, concepts and relationships," Int. J. Mach. Learn. Comput., vol. 1, no. 2, pp. 199-204, 2011.

[13] N. Jeerungsuwan, P. Nilsook, and P. Wannapiroon, “An analysis of web services and design of information management on vocational education websites in Thailand," in Proc. 2009 International Conference on Information and Multimedia Technology, 2009, pp. 319-322.

[14] B. Cheng, X. Cheng, and J. Chen, "Lightweight monitoring and control system for coal mine safety using REST style," ISA Trans., vol. 54, pp. 229-239, Jan. 2015.

[15] R. S. Bhadoria, N. S. Chaudhari, and G. S. Tomar, "The performance metric for enterprise service Bus (ESB) in SOA system: Theoretical underpinnings and empirical illustrations for information processing," Inf. Syst., vol. 65, pp. 158-171, Apr. 2017.

[16] K. Ahn, S. Park, H. Kim, J. Kim, and J. Park, "The design of SOA-based business collaboration system," in Proc. 2008 Fourth International Conference on Networked Computing and Advanced Information Management, 2008, pp. 707-712.

[17] H. Li and Q. Liu, "Design and implementation of educational information resource management system based on SOA," in Proc. 2008 International Symposium on Knowledge Acquisition and Modeling, 2008, pp. 424-428.

[18] H. Li and Z. Wu, "Research on distributed architecture based on SOA," in Proc. 2009 International Conference on Communication Software and Networks, 2009, pp. 670-674.

[19] B. Li, "Research and application of SOA standards in the integration on web services," in Proc. Second International Workshop on Education Technology and Computer Science, 2010, pp. 492-495.

[20] Office of the Education Council. (2016). The National Education Plan (for B.E. 2560-2579). [Online]. Available: http://www.onec.go.th/index.php/page/view/Outstand/2532\%0Ahttp:/ /www.onec.go.th/index.php/book/BookView/1540

[21] Ministry of Digital Economy and Society. (2016). The Digital Development Plan to Economy and Society. [Online]. Available: http://www.mdes.go.th/assets/portals/1/files/590613_4Digital_Econo my_Plan-Book.pdf 
[22] Office of the National Economic and Social Development Council. (2018). A National Strategy (for B.E. 2561-2580). [Online]. Available: http://www.ratchakitcha.soc.go.th/DATA/PDF/2561/A/082/T 0001.P $\mathrm{DF}$

Copyright (C) 2020 by the authors. This is an open access article distributed under the Creative Commons Attribution License which permits unrestricted use, distribution, and reproduction in any medium, provided the original work is properly cited ( $\underline{\text { C BY 4.0) }}$.

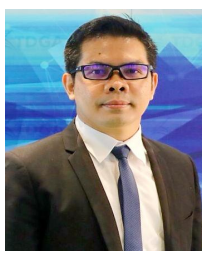

Worrapong Nuam-In is a Ph.D. candidate in information and communication technology for education at the Faculty of Technical Education, King Mongkut's University of Technology North Bangkok (KMUTNB), Bangkok, Thailand. He graduated with a master degree in computer science from the Faculty of Applied Science, King Mongkut's University of Technology North Bangkok (KMUTNB)and bachelor degree in computer science from the Faculty of Science, Nakhonsawan Rajabhat University. He is a computer specialist at the Office of the Basic Education Commission (OBEC), Ministry of Education.

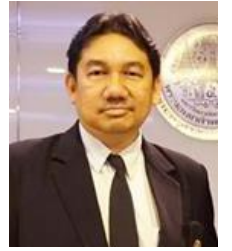

Prachyanun Nilsook is an associate professor at the Division of Information and Communication Technology for Education, King Mongkut's University of Technology, North Bangkok (KMUTNB), Thailand. He currently works in the field of ICT for education. $\mathrm{He}$ is a member of the professional society, the Association for Educational Technology of Thailand (AETT).

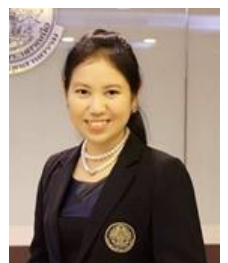

Panita Wannapiroon is an assistant professor at the Division of Information and Communication Technology for Education, King Mongkut's University of Technology, North Bangkok (KMUTNB), Thailand. Presently, she works in the field of ICT in education. She is a member of the professional societies, the Apec Learning Community Builders, Thailand (ALCoB) and the Association for Educational Technology of Thailand (AETT). 